\title{
THE DISTINCTION BETWEEN INFORMING AND PROSECUTORIAL INVESTIGATIONS: A FUNCTIONAL JUSTIFICATION FOR "STAR CHAMBER" PROCEEDINGS
}

A RECENT federal district court order casts doubt on the permissibility of holding public hearings in the course of an administrative investigation without granting procedural safeguards to subpoenaed witnesses. ${ }^{1}$ The order restrained an FTC Hearing Examiner from enforcing subpoenas directing officials of a large midwestern grocery chain (The Kroger Co.) to appear, produce documents, and testify at public hearings in connection with the FTC's investigation of a milk price war in Indianapolis. ${ }^{2}$ The Commission had denied Kroger's motion that either the hearings be held in private or that "full representation by counsel" be permitted. ${ }^{3}$ At previous public hearings Kroger's counsel had been denied opportunity to call or cross-examine witnesses, introduce evidence, or make statements and objections for the record.4

1. Hall v. Lemke, Trade Reg. Rep. (1962 Trade Cas.) I 70338 (N.D. Ill. May 7, 1962). No final order was entered in the case. The initial eight-day restraining order was continued until September 10, 1962 and argument was held on plaintiff's motion for a preliminary injunction. On June 20,1962, however, the Commission withdrew the challenged subpoenas. Trade Reg. Rep. If 10114.11. See also Archer v. Lemke, Trade Reg. Rep. If 70417 (N.D. III. July 20, 1962), discussed in note 54 infra.

2. The Kroger officials were originally subpoenaed along with those of two other interstate grocery chains and six local supermarkets. FTC News Release, Feb. 28, 1962, TRADE REG. REP. If 10114.10. After their objections to the Commission's procedures had been overruled by the Hearing Examiner, they refused to participate further in the hearings. The FTC then issued a second set of subpoenas to the Kroger officials alone, stating that these were for the purpose of continuing its previous investigation. These subpoenas were the subject of the District Court's restraining order. See FTC News Releases, April 27, and MaY 3, 1962, TrADE REG. REP. If 10114.11.

3. Hall v. Lemke, supra note 1.

4. The FTC's rules for investigatory proceedings in effect during the Indianapolis hearings provided in pertinent part that:

Any party compelled to testify or to produce documentary evidence may be accompanied and advised by counsel, but counsel may not, as a matter of right, otherwise participate in the investigation.

FTC Procedures, Rules of Practice, and Orders § 1.40, 20 Fed. Reg. 3057 (1955) (superseded June 1, 1962). Presumably both the Hearing Examiner and the Commission were relying on this rule in denying the rights claimed by plaintiffs. Brief for Defendant, pp. 7-8, 13, Hall v. Lemke, supra note 1.

The FTC's current rules for investigative proceedings took effect on June 1, 1962, 27 Fed. Reg. 4609-23 (May 16, 1962), shortly after the issue of the restraining order in the Hall case. These rules leave the former provision unchanged for nonpublic investigations, but provide further that witnesses compelled to testify at public hearings:

may be accompanied, represented, and advised by counsel: Prozided, however, that such representation shall not include the right to call, examine or cross-examine witnesses, or adduce evidence.

Id. at 4610. The FTC Chairman subsequently indicated that, in practical effect, the Com- 
In seeking the order Kroger contended that since the hearings would involve express and implied accusations of illegal conduct, it would be a denial of due process to hold the hearing in public without providing adequate opportunity for rebuttal. ${ }^{5}$ Kroger also argued that the proceeding was unauthorized because the Federal Trade Commission Act does not give the FTC power to use public hearings in its investigations. ${ }^{6}$ The Commission contended in turn that the trial-type procedural safeguards sought by Kroger were not constitutionally required in investigative, as distinguished from adjudicatory, proceedings, ${ }^{7}$ and that the procedural safeguard of holding the hearing in private was not required by the act. ${ }^{8}$ The district court's restraining ${ }^{0}$ order, issued without a

mission's newly-created "right to representation" in public hearings may be limited to the "noting of proper objections to questions." FTC News Release, July 6, 1962. The Commission had already offered to grant Kroger's counsel this right upon the resumption of the Indianapolis hearings. Brief for Defendant, p. 13, Hall v. Lemke, supra.

A Federal District Court recently enjoined enforcement of FTC subpoenas for a thonpublic investigative hearing on the ground that Rule $\S 1.40$, when construed to deny plaintiff's counsel opportunity to present concise objections on the record to questions deemed improper, did not comply with $\S 6$ (a) of the Administrative Procedure Act, 60 Stat. 240 (1946), 5 U.S.C. \& 1005 (a) (1958), which the court held applicable to the Commission's nonpublic investigative proceedings. Wanderer v. Kaplan, TrADE REG. REP. (1962 Trade Cas.) If 70535 (D.D.C. Oct. 30, 1962). Apparently responding in part to this decision, the FTC recently decided by a 3-2 vote to modify its practices in nonpublic investigative hearings to permit presentation of objections on the record and to expand generally the role of witnesses' counsel. Wall Street Journal, Jan. 14, 1963, p. 4, col. 3. Thus there would not appear at present to be any significant difference in practice between the witness' procedural rights in public and nonpublic investigations.

5. Brief for Plaintiff, p. 3, 27-28, Hall v. Lemke, supra note 1. See Letter from John de J. Pemberton, Jr., Executive Director of the American Civil Liberties Union, to Paul Rand Dixon, Chairman of the FTC, April 20, 1962, on file at Yale Law Library.

6. Brief for Plaintiff, pp. 17-26, Hall v. Lemke, supra note 1.

7. Brief for Defendant, pp. 25-31, Hall v. Lemke, supras note 1. The Commission based this contention primarily on the Supreme Court's decision in Hannah v. Larche, 363 U.S. 420 (1960), discussed infra at notes $28-42$.

8. Brief for Defendant, pp. 18-25, 31-33, Hall v. Lemke, supra note 1. The FTC did not argue that statutory authority for public hearings had been specifically granted. It cited SEC v. Harrison, 80 F. Supp. 226 (D.D.C. 1948), where the District Court indicated that the choice between open or closed hearings "must rest in the sound discretion of the agency created by the Congress, and not with the courts . ..." Id. at 229. Though the opinion does not deal explicitly with the question of procedural safeguards, it appears also from the statement of facts by Morris, J., that opportunity to cross-examine adverse witnesses had been denied at the hearing. Id. at 227. In Harrison the court refused injunctive relief against at public investigation where the plaintiff attorneys had been compelled to testify about an alleged collusive suit against a company issuing stock so that an underwriting company could take advantage of an "escape clause." See also Schmidt v. United States, 198 F.2d 32 (7th Cir. 1952) (suit under Federal Tort Claims Act dismissed under exception for discretionary powers where stockholder claimed injury from publication of facts surrounding SEC's investigation of Tucker (three-wheel automobile) Corporation and the release of a confidential report to the press).

The District Court in Harrison did not cite any case law or other authority for its view that the choice of public or private hearings is entirely a matter of agency discretion, nor did it otherwise explicate the considerations impelling it to reach this conclusion. Though it 
discussion of the underlying rationale, stated that holding public hearings without permitting "full representation by counsel" would jeopardize the company's good will and subject it to "irreparable" economic injury.10

Though the court did not make explicit the grounds of its decision, the case would appear to raise an issue of constitutional dimension: In what kind of agency proceedings does due process of law require that persons be protected by either executive hearings or trial-type safeguards against the impact of adverse publicity arising from the proceeding? Frequently recognized in administrative law is a distinction between adjudicatory proceedings-those in which findings of fact serve as the basis for the imposition of official sanctions or other action affecting a "substantive right"11 - where the traditional trialtype safeguards of procedural due process have been found to apply, ${ }^{12}$ and investigatory proceedings- where such safeguards have been found unnecessary. ${ }^{13} \mathrm{~A}$ further distinction seems relevant in determining what due process

could conceivably have relied on Wooley v. United States, $97 \mathrm{~F} .2 \mathrm{~d} 258,262$ (9th Cir.), cert. denied, 305 U.S. 614 (1938), that case held only that $\S 21$ of the Securities Act of 1933 ("All hearings shall be public..."), 48 Stat. 86, 15 U.S.C. § 77u (1958), does not prevent the SEC from holding investigative hearings in prizate. Furthermore, there is some indication in the Harrison opinion that the court regarded the question of public versus closed hearings as incidental to what it conceived as the central issue; vij., whether the attorney-client privilege was applicable in the investigative proceeding. Id. at 230 . Thus qualified, the case does not seem to be persuasive authority for the position that agencies may hold public investigative hearings in their sole discretion.

9. The court stated that the plaintiffs had been threatened with criminal penalties under Section 10 of the Federal Trade Commission Act, 38 Stat. 723 (1914), 15 U.S.C. $\$ 50$ (1958), and indicated that this in itself might have been a sufficient basis for jurisdiction to grant injunctive relief in advance of attempted enforcement by the Commission. Hall v. Lemke, supra note 1. Compare United States v. St. Regis Paper Co., 285 F.2d 607, 615-16 (2d Cir. 1960), aff'd on other grounds, 368 U.S. 208, 225-27 (1961) with FTC v. Claire Furnace Co., 274 U.S. 160 (1927). The latter case was criticized in Handler, The Constitutionality of Investigations by the Federal Trade Consmission I, 28 CoLuar. L. REv. 708, 714-20 (1928).

10. This Note does not deal with the showing of probable irreparable injury which should be prerequisite to injunctive relief against a public investigative hearing or to a refusal to enforce agency subpoenas for such hearings. The assumption that the threat of harm is sufficient to warrant injunctive relief is made throughout in order to preserve the focus on the constitutional issues raised by public proceedings without safeguards. Courts might be more likely to question the likelihood and extent of injury in the context of economic investigations like that involved in the principal case, particularly where the conduct investigated, though potentially illegal, is not widely disapproved by the public. But see United States Attorney General's Committee on Administrative Procedure, Mfonograph on the Federal Trade Commission, S. Doc. No. 186, 76th Cong., 3d Sess. 9 (1940), and Rourke, Law Enforcenent Through Publicity, 24 U. CHI. L. Rev. 225, 231-38 (1957), a useful treatment of the "publicity sanction" as it relates to various areas of governmental activity and of the factors on which its efficacy may depend.

11. See 1 Davis, Administrative Law Treatise $\$ 7.02$ (1958).

12. Morgan v. United States, 304 U:S. 1, 14, 18-19 (1938); Greene v. AfcElroy, 360 U.S. 474, 496-97 (1959) (dictum); see Atr'y Gen. Coarar. Adsrrs. Proc. ReP. 62 (1941); Administrative Procedure Act, $\$ 7(c), 60^{\circ}$ Stat 241,5 U.S.C. $\$ 1006$ (c) (19j8).

13. See Bowles v. Baer, 142 F.2d 787, 789 (7th Cir. 1944); In re Groban, 352 U.S. 330, 333 (1957) ; Hannah v. Larche, 363 U.S. 420, 446-48 (1960), discussed at notes 28-42 infro; cf. Note, 58 CoLUM. L. REv. 395, 401-03 (1958). 
demands in an "investigative" proceeding, like the FTC hearing involved in the instant case. An investigation may be designed principally to gather information as a basis for formulating administrative rules or proposing legislation to the Congress, or it may be designed to uncover facts about specific persons in preparation for an administrative prosecution. Existing case law does not provide direct support for a distinction between the requirements of procedural due process in informing and pre-prosecutorial hearings. An examination of the doctrines which protect against possible adverse publicity in other governmental proceedings- such as congressional investigations and grand jury hearings-indicates, however, that this distinction should be recognized in determining what process is due in agency non-adjudicatory proceedings. The utility of such a distinction is that it directs attention to the critical factors which must be weighed in formulating procedural requirements that strike a proper balance between the individual's need for protection against extraofficial sanctions and the government's interest in gathering information and generating consent for governmental action.

While the Supreme Court, in reviewing congressional contempt actions against recalcitrant witnesses, has taken note of the extra-official deprivations produced by compelled disclosures and the testimony of adverse witnesses, ${ }^{14}$ it has never explicitly explored the relationship between the denial of procedural safeguards ${ }^{15}$ in congressional hearings and the possibilities of harm through publicity. Thus the Court has not used its jurisdiction over contempt convictions as a vehicle for exercising judicial control over the grouncl-rules of congressional investigations or for placing limits on the use of public hearings. ${ }^{16}$ While the Court's reluctance to intervene in this area probably stems in part from deference toward a coordinate branch of government, ${ }^{17}$ it may be inferred from the Court's frequent stress on the broad "informing" function of Congress ${ }^{18}$ that its attitude bears a considerable relation to the distinction

14. See Watkins v. United States, 354 U.S. 178, 197-98 (1957).

15. On the extent to which procedural safeguards are denied in congressional investigations, see, e.g., Rauh \& Pollitt, Right to and Nature of Represcutalion beforc Congressional Conmittees, 45 MINn. L. Rev. 853, 854-55 (1961) ; Galloway, Congressional Investigations: Proposed Reforms, 18 U. CHr. L. Rev. 478, 480-82, 490-502 (1951) (examining various legislative proposals and suggested reforms to provide safeguards for witnesses).

16. See Taylor, Jidicial Review of Legislative Investigations, 29 NotRe DAME LAw. 242, 275-76 (1954) ; Hannah v. Larche, 363 U.S. 420, 497 (1960) (dissenting opinion) ; cf. United States v. Kleinman, 107 F. Supp. 407, 408 (D.D.C. 1952). The issue of judicial control over the procedures of congressional committees was raised in Kleinman, a case arising out of the Kefauver Crime Committee hearings, when the defendant resisted an indictment for contempt on the ground that the use of live television at the hearings, as permitted by the Committee's Rules, was a denial of due process. The court rejected this contention, but dismissed the indictment after finding that defendant's refusal to answer was justified because of the "disturbing" and "distracting" elements in the hearing room. See also Note, 26 TEMP. L. Q. 70 (1952) ; Note, 51 Micr. L. REv. 1072 (1953).

17. Sec Taylor, supra note 16 at $277,283$.

18. McGrain v. Daugherty, 273 U.S. 135, 174-80 (1927); see Barenblatt v. Unitcd States, 360 U.S. 109, 111-12, 132-33 (1959); Wilkinson v. United States, 365 U.S. 399, 409-12 (1961). 
proposed above. Some opinions imply that this function serves to inform the public as well as the Congress. ${ }^{19}$ When the legislature uses its investigative powers to inform the public, it stimulates a flow of further information and preferences from the public which may decisively influence legislative views as to the necessity and character of prospective enactments. Since such channels of communication are increasingly vital to the workability of modern representative government, the Court may be reluctant to obstruct congressional investigations with trial-type procedures or to divert their course by requiring closed hearings. Under this interpretation of the Court's decisions, the witness' protection against adverse publicity and his opportunity for defense against charges appears extremely attenuated in a congressional proceeding that is designed to inform, ${ }^{20}$ because of the necessity and importance of the informing function. ${ }^{21}$

The grand jury investigation may be contraposed to the congressional inquiry, since the former is employed primarily to secure prosecutorial information.22 Grand jury proceedings provide few trial-type procedural safeguards for potential subjects of indictment, ${ }^{23}$ but are traditionally, ${ }^{24}$ and perhaps constitutionally, ${ }^{25}$ required to be held in private. Where accusations or suspicions are found lacking in reasonable foundation, they are withheld entirely from the public. If an indictment is returned after an $c x$ parte grand jury proceeding, the subject may well be exposed to extra-official sanctions. ${ }^{20}$ And although the indictment is not the product of a full adversary proceeding, its

19. See United States v. Rumely, 345 U.S. 41,43 (1953) ; Wathins v. United States, 354 U.S. 178, 187 n.8, 200 n.33 (1957); WILson, Congressional. Governasent 303 (7th ed. 1890).

20. Cf. Barenblatt v. United States, 360 U.S. 109, 126-27 (1959); Wilkinson v. United States, 365 U.S. $399,410,414-15$ (1961).

21. This conclusion and the analysis developed in this paragraph are based considerably on the discussion in Bicker, The Least Dangerous Branch 156-64 (1962).

22. See Barth, Governiment by Investigatron 71 (1955).

23. Dession \& Cohen, The Inquisitorial Functions of Grand Juries, 41 YALE L.J. 687, 700 (1932); A. Goldstein, The State and the Accused: Balance of Advantage in Criminal Procedure, 69 Y ALE L.J. 1149, 1190-91 (1960).

24. United States v. Johnson, 319 U.S. 503, 513 (1943); United States v. Costello, 350 U.S. 359, 362 (1956) ; see Fed. R. CRIM. P. \$ 6(e).

25. Application of United Elec. Workers, 111 F. Supp. 858, 861, 865-70 (1953). The violation of secrecy in this case consisted in disclosing to the press the names of thirteen union officials who had been investigated concerning the non-Communist affidavits they had filed pursuant to former $\S 9(\mathrm{~h})$ of the Taft-Hartley Act and in the publication of a special "presentment" alleging that the officials had committed perjury in filing the affdavits. Judge Weinfeld emphasized particularly the interrelationship between harm through adverse publicity and the absence of procedural safeguards in grand jury investigations :

Protection of those against whom the prosecution cannot in ex parte proceedings make out a sufficient case to warrant indictment is defeated when the fact of suspicion and the proceedings had thereon before the Grand Jury are given widespread publicity in a report. ... The damage ensuing from specific reports results ... from disregard of the traditional safeguards of an adversary proceeding and public hearing.

Id. at 866,868 .

26. See Note, 72 YaLE L.J. 590 n.6 (1963). 
impact arguably is reduced by the fact that it is not preceded by repeated and detailed public accusations of wrongdoing. Consistent with the presumption of innocence operative in criminal cases, the secrecy of the grand jury proceeding keeps at a minimum the imposition of pre-trial unofficial sanctions. ${ }^{27}$ Since the prosecutor is not specifically charged with the responsibility of developing legislative recommendations or directly prescribing rules of condtuct, the restrictions which secrecy imposes on the flow of information between his office and the public at the investigative stage of prosecution thus represent a desirable form of protection against the extra-official sanctions which wotld otherwise accompany the proceeding.

In Hannah $v$. Larche ${ }^{28}$ the Supreme Court dealt extensively for the first time with the question of witnesses' protection in federal administrative investigations. ${ }^{29}$ The Court considered the applicability of trial-type procedural safeguards, such as cross-examination, notice of charges, and confrontation, in the investigative proceedings of the Civil Rights Commission where involuntary witnesses claimed that their appearance and testimony at certain public hearings ${ }^{30}$ would subject them to severe extra-official sanctions. The

27. See United States v. Johnson, 319 U.S. 503, 513 (1943).

28. 363 U.S. 420 (1960). The case has been analyzed at length in two articles by Dean Newman: Due Process, Investigations, and Civil Rights, 8 U.C.L.A.L. REv. 735 (1061); and Federal Agency Investigations: Procedural Rights of the Subpoctacd Wilncss, 60 MICH. L. REv. 169, 173-80 (1961).

29. In re Groban, 352 U.S. 330 (1957), held 5-4 that witnesses subpoenaed to testify in an investigation conducted by a state Fire Marshal were not entitled to the presence or participation of their counsel. In excluding counsel, the Marshal had acted under a statutory provision which permitted, but did not require him, to hold the investigative procecding in private. The Court stated that the proceeding was not adjudicatory in nature, but designcd "to elicit facts relating to the causes and circumstances of the fire"-accordingly, the witnesses' rights were sufficiently protected by the privilege against self-incrimination. $I d$. at 332-33. In concurring, Justice Frankfurter emphasized the distinction between "a secret inquisition of those suspected of arson" and a "general administrative non-prosecutorial inquiry into the causes of fire," which he considered to be the proper construction of the proceeding authorized in the Ohio statute. Id. at 336, 337 (concurring opinion).

Groban was followed in. 1959 by Anonymous v. Baker, 360 U.S. 287 (1959), another 5-4 case. The Court held that witnesses in a state judicial inquiry concerning alleged ambulancechasing among members of the local bar were not denied due process when the presiding judge required their counsel to remain outside the hearing room, but permittcd the witnesses to consult freely with counsel during the interrogation. The Court placed some emphasis on the protective function performed by secrecy in the circumstances, $i d$. at 291-92, and stated that Groban was controlling on the issue of a constitutional right to the presence and participation of counsel. Id. at 295-96.

The majority opinion in Hannah v. Larche, supra note 28, relegated both cases to a footnote because of "significant differences between them and the instant litigation" and because it viewed the result in Hannah as "supported by other considerations." Id, at 451 n.31. Justices Harlan and Clark, however, thought that the Groban and Baker decisions were totally dispositive of the issues presented in Hamnah. Id. at 485 (concurring opinion).

30. The plaintiffs in Hamah, like the Kroger officials in Hall v. Lemke, 5 TRADE REG. REP. (1962 Trade Cas.) If 70338 (N.D. Ill. May 7, 1962), had sought declaratory relief against a scheduled investigative hearing. Neither the Supreme Court nor the District Court opinion in Hannah states explicitly that the hearings were to be public, but Justices 
Court ${ }^{31}$ held that there was no constitutional right to the procedural safeguards of a trial in the Commission's investigations. In reaching this conclusion, the Court stated that the commission's primary function was to gather information and that its investigations were not a prelude to criminal prosecution or other proceedings leading to official deprivations. Thus the introduction of procedural safeguards would have only a disruptive effect on the Commission's hearings. ${ }^{32}$ In answering the argument that protection against potential extra-official deprivations was required, the Court stated that:

... even if such collateral consequences were to flow from the Comnission's investigations, they would not be the result of any affirmative determinations made by the Commission, and they would not affect the legitimacy of the Commission's investigative function. ${ }^{33}$

This crucial passage of the opinion suggests that the Court, while relying chiefly on the "informing" nature of the Commission's proceedings, was seeking also to place its holding on a broader ground. The Court's theory with regard to extra-official deprivations appears to be that witnesses are not entitled to protection against these deprivations unless the proceeding which generates them eventuates in an "affirmative determination," a quasi-verdict of guilt that triggers public opprobrium. Under this theory, the witness' right to protection would depend not on the extent to which the proceeding was designed to serve an informing purpose, but on whether it led either to official deprivations ("punishment") or to a final official determination ("verdict"). The Court did not make clear whether a focused pre-prosecutorial hearing, in which information is sought to determine if a prosecution against specific individuals should ensue, falls within the latter category. Since preprosecutorial and informing hearings traditionally have been classified indiscriminately under the rubric of investigative proceedings, and since the Court apparently refused to inquire into the specific purpose of the proposed hearings in Hamnah, it is not likely that the Court was making a distinction between these two types of investigative proceedings in that case. Thus Hamals may be read as holding that if the hearings are not adjudicative in the traditional sense of that term, conducting an administrative proceeding in public and without trial-type safeguards does not raise due process questions, even though

Frankfurter, id. at 492 (concurring opinion), and Douglas, id. at 496 (dissenting opinion), noted that the Civil Rights Commission was authorized to hold public hearings. The District Court's emphasis on the potential injury to the witnesses' reputations, Larche v. Hannah, 177 F. Supp. 816, 822, 828 (W.D. La. 1959) also would seem to support the inference that the Commission's scheduled hearings were to be public. FTC and Kroger's counsel disagreed on this point. Compare Reply Brief for Plaintiff, p. 28, with Brief for Defendant, p. 27, Hall v. Lemke, supra. The FTC, however, introduced an affidavit from the Civil Rights Commission's General Counsel stating that the hearings involved in Homsoh were to be public. Reply Brief for Defendant, p. 9, Hall v. Lemke, sipra.

31. The decision was by a majority of seven to two. Though joining the opinion of the Court, Justices Harlan and Clark also filed a brief concurring opinion. See note 29 supra. Mr. Justice Franlfurter concurred in the result, and Justices Black and Douglas dissented.

32. Hannah v. Larche, 363 U.S. 420, 443 (1960).

33. Ibid. 
an "informing" purpose has not been established." The majority thus dis" tinguished Joint Anti-fascist Refugee Committee v. McGrath, ${ }^{36}$ a case which lends support to the view that some requirements of procedural due process are applicable where an administrative "determination" actuates an extraofficial sanctioning process. ${ }^{36}$ The distinguishing feature of Anti-fascist, according to the Court in Hannah, was that the Attorney General's ex parte designiation of the complainant organizations as "Communist" was tantamount to an "adjudication."37

In his concurring opinion in Hannah, Mr. Justice Frankfurter agreed with

34. The majority's treatment in dictum of the FTC's rules for investigative proceed ings-see note 4 supra-and those of other regulatory agencies such as the SEC suggests that it did not regard the distinction between informing and pre-adjudicative hearings as one of constitutional significance. Id. at 446-48. The Court stated that :

We have found no authorities suggesting that the rules governing Federal Trade Commission investigations violate the Constitution, and this is understandable since any person investigated by the Federal Trade Commission will be accorded all the traditional judicial safeguards at a subsequent adjudicative proceeding.

Id. at 446. See also FCC v. Schreiber, 201 F. Supp. 421, 423 (S.D. Cal. 1962); Alabama ex rel. Gallion v. Rogers, 187 F. Supp. 848, 854 (M.D. Ala. 1960).

The significance of this dictum in the present context is arguably reduced by the fact that it antedates the FTC's recently-instituted practice of holding pre-prosecutorial hearings in public. See note 49 infra. The Hannah majority, however, appears to have been equally insensitive to the possibility of a critical distinction between public and private hearings without safeguards, as reflected by its reliance on the procedures of both gratid juries, Hannah v. Larche, sipra note 31 at $448-49$, and congressional investigations, id. at $444-45$, in support of its holding.

The theory of this Note is not inconsistent with either the result in Hannah or the Court's approach to the functions of the Civil Rights Commission. The Note does rest, however, on a rejection of some of the broader implications of the Hamah opinion. See also text at notes 38-42 infra.

35. 341 U.S. 123 (1951).

36. In Anti-fascist the Attorney General had designated the three petitioner organizations as "Communist" without giving them notice or hearing; the organizations claimed that their membership and financial support had been impaired as a result of the consecftent injury to their reputations. There a fragmented majority of five Justices agreed that the District Courts had erred in dismissing the organizations' suits for declaratory and injunctive relief. There was no opinion of the Court, but Mr. Justice Dotglas joined Mr. Justice Burton in the view that the Attorney General had admitted his designation to be "patently arbitrary" (and therefore in excess of his authority under the Executive Order establishing the loyalty program) in his motion to dismiss. Joint Anti-fascist Refugec Comm. v. McGrath, supra note 35 at 136-42. In a separate opinion, however, Justice Douglas agreed with Justices Black, $i d$. at 142-50, and Frankfurter, id. at 150-74, who also wrote separate opinions, that the summary designation procedure was unconstitutional. Id. at $174-79$.

Justice Jackson was the only member of the majority adhering to a rigid distinction between sanctions imposed by "public disapproval" and those imposed "by law." Id. at 184. Though he agreed that it was a denial of due process "to promulgate with force of law a conclusive finding of disloyalty, without hearing ...," id. at 186, he characterized the organizations' right to relief upon their own claim as "very dubious," $i d$. at 184, and joined the majority only because he thought the designated organizations were entitled to vindicate the rights of government employees who were subject to discharge for membership. Id. at 186-87.

37. Hannah v. Larche, 363 U.S. 420, 452 (1960). 
the majority that the Commission's function was investigative rather than adjudicative, for it had no power to pass official adverse judgments on individuals; its responsibility was "to gather information as a solid foundation for legislative action," and its rules manifested an adequate adherence to this limited investigative responsibility. ${ }^{38}$ In discussing the relationship of the Antifascist case to the issues before the Court, however, Mr. Justice Frankfurter did not accept the absence of an official determination in Hammah as a sufficient ground of distinction. ${ }^{39} \mathrm{He}$ developed the contrast between the two situations more fully and relied considerably on section 102(e) of the Civil Rights Act of 1957 , which provides that:

If the Commission determines that evidence or testimony at any hearing may tend to defame, degrade or incriminate any person, it shall (1) receive such evidence or testimony in executive session; . . . and (3) receive and dispose of requests from such persons to subpoena additional witnesses. ${ }^{40}$

Thus, he stressed that this provision was a "safeguard against injury to persons who appear in public hearings." 41 This emphasis on the effort of Congress to provide a measure of protection against possible extra-official deprivations implicitly rejects the view that protection against such deprivations is not a relevant due process consideration where an element of official "determination" or "deprivation" is absent. 42

Accepting Justice Frankfurter's implicit contention that deprivations generated by agency proceedings are no less worthy of judicial protection because they do not flow directly from official determinations, the denial of protec-

38. Id. at 488-89, 492-93 (concurring opinion).

39. See id. at 490-92 (concurring opinion).

40. 71 Stat. 634 (1957), 42 U.S.C. \& 1975a(e) (1958). Section 102(g) of the Act provides that "... . evidence or testimony taken in executive session may [not] be relcased or used in public sessions without the consent of the Commission. Whoever releases or uses in public without the consent of the Commission evidence or testimony taken in exceutive session shall be fined not more than $\$ 1,000$, or imprisoned for not more than one year." 71 Stat. 634 (1957), 42 U.S.C. $§ 1975 \mathrm{a}(\mathrm{g})$ (1958).

41. Hamah v. Larche, 363 U.S. 420,492 (1960) (concurring opinion). There is some reason to question the strength of $\S 102(\mathrm{e})$ as a safeguard, however. Under its terms, the duty of the Commission to receive testimony in executive session arises if the Commission determines that the testimony may tend to defame, degrade, or incriminate any person. Even though the Commission's duty can readily be construed as mandatory by taking the conditional expression to refer to the outcome rather than to the making of the determination, the problem of framing a procedure and standards for some measure of judicial control, however modest, has to be solved before the protection can be deemed adequate. But the statute provides no guidelines for judicial review and $\S 102(\mathrm{~g})$-see note 40 sipra-appears to complicate the problem by its suggestion that the Commission's "consent" is a sufficient basis for the lawful release of testimony taken in executive session.

42. See also Joint Anti-fascist Refugee Comm. v. AfcGrath, 341 U.S. 123, 157-61 (1951) (concurring opinion), and $i d$. at 173-74:

Nor does [the Attorney General] obtain immunity on the ground that designation is not an "adjudication" or a "regulation" in the conventional use of those terms. Due process is not confined in its scope to the particular forms in which rights have 
tion may nevertheless be justified in certain circumstances. The "informing" function with characterizes congressional hearings may be exercised most effectively through public hearings without trial-type procedural obstructions. An agency which is authorized to conduct investigations and to gather information for rule-making or recommending legislation has a valid interest in pursuing this objective. In such investigations a primary function of the process is to reach an external audience which includes the Congress, those segments of the public which are primarily affected by the agency's regulatory policies, and the body politic itself. While the use of public hearings is not strictly necessary for the dissemination of the information produced, the publicity generated by the gathering of raw data may contribute substantially to the effectiveness of the informing process. It is true that the informing purpose of a hearing is not a complete safeguard against the dissemination of considerable "misinformation" to the public which may result in harm to witnesses or others. While this possibility reduces the weight of the "informing" justification in particular instances, it does not appear to be a sufficient reason for disallowing public hearings or imposing a general requirement that the safeguards of a trial be provided where the agency's genuine concern is to develop information for prescribing or proposing future rules of conduct. Thus, the reasons that have led the Court not to impose procedural safeguards on congressional hearings that serve the informing function should lead to the same result where an administrative agency undertakes hearings that serve the same function.

But all agency non-adjudicatory proceedings are not intended to give content to or generate consent for rule-making or legislative proposals. An agency which is authorized to enforce regulatory legislation also investigates conduct suspected of violating the statute before committing itself to a full-scale administrative prosecution. Investigations designed to gather information upon which a determination of whether to prosecute specific individuals is to be based, though sometimes procedurally resembling hearings designed to inform, are pre-prosecutorial proceedings which serve a different purpose from what may be termed pre-legislative investigations. Although the quantum of harm to an individual in the form of injury to reputation flowing from both types of proceedings may be identical in some circumstances, the reasons for denying due process procedural safeguards in hearings intended to inform are far more compelling than in the case of pre-prosecutorial investigations. Such investigntions are strikingly similar in purpose to grand jury proceedings and the rethsons adumbrated above for requiring grand jury proceedings ${ }^{43}$ to be conducted

heretofore been found to have been curtailed for want of procedural fairness . . . . While it contains the garnered wisdom of the past in assuring fundamental justice, it is also a living principle not confined to past instances.

43. The inveterate analogy to the grand jury in judicial discussions of the power of administrative investigation is not always a happy one. See United States v. Morton Salt Co., 338 U.S. 632, 642-43 (1950) ("[a]n administrative agency charged with secing that the laws are enforced .... has a power of inquisition, if one chooses to call it that, which is not derived from the judicial function. It is more analogous to the Grand Jury, which does 
en camera would seem applicable also to pre-prosecutorial administrative investigations, ${ }^{44}$ at least where such investigations are likely to generate substantial adverse publicity against a particular individual. ${ }^{\text {s }}$

It might be argued that a pre-prosecutorial administrative proceeding differs in an important respect from the typical grand jury investigation. Though the probable existence of facts constituting a statutory violation is a primary focus of the agency's inquiry, other considerations, such as the prevalence of the particular practice and its importance in relation to the statutory objectives, will also enter into the agency's decision to prosecute. The argument, however, fails to observe that a grand jury proceeding frequently serves a similar function by supplying the prosecutor with information which goes beyond probable cause for prosecuting a particular individual. ${ }^{20}$ This information enables the prosecutor to make an initial evaluation of the extent of a particular criminal practice, the impact of such behavior on the community, the difficulties of proving and punishing the behavior under existing law, and so forth. This kind of information may be essential to a determination of the most effective means of employing the limited resources available to any prosecutorial agency.

An agency's need for a public hearing in order to obtain information and views on the broader problems, however, should not be conclusive where there is a substantial probability of a harmful extra-official impact on the subjects of the investigation..$^{47}$ Much of the information that is relevant to the agency's estimate of the scope of the practices under investigation and their

not depend on a case or controversy for power to get evidence but can investigate merely on suspicion that the law is being violated, or even just because it wants assurance that it is not.") See also Oklahoma Press Publishing Co. v. Walling, 327 U.S. 186, 216 (1946), a milestone along the path to virtual abdication of effective judicial control of agency subpoenas.

44. Cf. Bowles v. Baer, 142 F.2d 787, 789 (7th Cir. 1944); In re SEC, 14 F. Supp. 417, 419 (S.D. N.Y. 1936), affd, 84 F.2d 316, 318 (2d Cir.), rev'd as moot sub nom. Braclien v: SEC, 299 U.S. 504 (1936). The result of requiring that federal agency investigations be held in private under certain circumstances, of course, would not be a true "star chamber" proceeding. Section 6(a) of the Administrative Procedure Act grants "any person compelled to appear in person before any agency or representative thereof ... the right to be accompanied, represented and advised by counsel ..." 60 Stat. 240 (1946), 5 U.S.C. § 1005(a) (1958). This section has been held applicable to administrative investigations, United States v. Smith, 87 F. Supp. 293 (D. Conn. 1949), and to the nonpublic investigations of the FTC. Wanderer v. Kaplan, Trade REg. Rep. (1962 Trade Cas.) If 70535 (D.D.C. Oct. 30, 1962). Thus traditional hostility to secret inquisitorial proceedings outside the grand jury context, see, e.g., In re Groban, 352 U.S. 330, 337-47, 351-53 (1957) (dissenting opinion), would not seem to be appropriately directed toward a private investigation conducted by an agency subject to the requirements of the APA.

45. In Anonymous v. Baker, 360 U.S. 287 (1959), discussed in note 29 supra, the Court indicated that secrecy was particularly appropriate as a protection of individual reputation in an investigation touching on the activities of members of the bar. See id. at 291-92 (quoting Chief Judge Cardozo in People ex rel. Karlin v. Culkin, 248 N.Y. 465, 478-79, 162 N.E. 487, 492 (1928)).

46. See Note, The Grand Jury as an Investigatory Body, 74 HaRv. L. REv. 590 (1961).

47. See note 10 supra. 
impact throughout its regulatory jurisdiction can be developed through its power to require the filing of reports by the businesses or other persons subject to its control. ${ }^{48}$ This information can be supplemented by depositions and oral testimony in private proceedings. While a private proceeding is less likely to apprise members of the public that the agency is considering a problem concerning which they may have information to offer, the use of official at1nouncements and press releases should enable the agency to reach a significant segment of the interested public.

These considerations suggest that a regulatory agency's efforts to make optimum use of its enforcement machinery would not be severely hampered by a requirement that pre-prosecutorial investigations be held in private. ${ }^{40}$ The goal of minimizing the occurrence of extra-official deprivations prior to an official finding that statutory violations have been committed is, of course, the justification for this limitation on the use of public hearings. While some prejudgment of guilt is certain to occur in the course of an agency investigation as a result of announcements that the investigation has been ordered or that an adjudicatory proceeding will take place,, 0 the impact of extra-official deprivations should not be accentuated by a public proceeding in which safeguards are denied.

48. Section 6(b) of the Federal Trade Commission Act gives the Commission power to: require, by general or special orders, corporations engaged in commerce ... to file with the commission in such form as the commission may prescribe annual or special, or both annual and special, reports or answers in writing to specific qutestions, furnishing to the commission such information as it may require as to the organization, business, conduct, practices, management, and relation to other corporations, partner ships, and individuals of the respective corporations filing such reports or answers in writing.

38 Stat. 721 (1914), 15 U.S.C. § 46(b) (1958).

49. Until recently the FTC itself has apparently followed a uniform practice of holding its pre-prosecutorial investigations in private. See address by Paul Rand Dixon, Marquette Law School Annual Banquet, May 2, 1962, printed as The Federal Trade Commission: Its Fact-finding Responsibilities and Pozvers, 46 MArg. L. REv. 17, 27 (1962) [hereinafter cited as Dixon; The Federal Trade Commission] ; cf. TRADE REg. REp. ff 50117 (1962).

In its rules, the Commission has provided for public hearings without formal distinction among the various types of investigations. The present rule provides that "investigative proceedings shall not be public" unless otherwise ordered by the Commission, while the rule in effect from 1955 to 1962 provided that "all investigatory hearings shall be nonpublic" unless otherwise ordered. Compare FTC Procedures, Rules of Practice, ANi ORDERS § 1.41, 27 Fed. Reg. 4610 (May 16, 1962), with § 1.41, 20 Fed. Reg. 3057 (1955) (superseded June 1,1962). It is difficult to evaluate the extent to which this nuturce reflects a change in FTC policy to favor a more active use of public hearings. But sec note 54 infra.

50. In E. Griffith Hughes, Inc. v. FTC, 63 F. 2d 362 (D.C. Cir. 1933), the coutt denied injunctive relief against a scheduled public hearing where the FTC had isstucd a formal contplaint charging the getitioner with unfair competition through fraudulent advertising. The court rejected petitioner's contention that the FTC's function was "wholly inquisitorial" and "necessarily secret" until final determination, stating that "where ... the possibility of loss is founded wholly on the public knowledge that an investigation has been ordered, no good reason exists or can be shown why the public hearing should not continue." Id. at 363-64. 
A requirement that such safeguards as the right to cross-examine and to introduce evidence in rebuttal be granted when pre-prosecutorial investigations are held in public offers a possible alternative to private hearings as a means of protecting witnesses. These adversary practices would be consistent with the fact-finding goals of the investigation and thus might further be justified as a safeguard against ill-founded adjudicatory proceedings which subject persons to unwarranted notoriety. It is far from clear, however, that trialtype safeguards are necessary for a fair determination that the probability of certain facts is sufficient to warrant further proceedings. Where a determination adverse to the subject of the investigations leads only to a civil proceeding for a cease-and-desist order against further violations of a regulatory statute and not to a criminal trial, the quantum and reliability of evidence upon which the decision to prosecute is based and the consequences of a prosecution itself appear to be far less significant. Thus, trial-type procedures, which primarily insure the validity of the decision to prosecute rather than effectively minimize adverse publicity arising from statements made in a public proceeding, do not seem necessary in administrative pre-prosecutorial investigations. Moreover, if an agency's interest in an expeditious determination of whether to prosecute is thwarted by making the preliminary investigation a replica of a formal adjudication, agencies may by-pass the preliminary investigation and proceed to adjudicate in situations where a preliminary investigation might otherwise have been ordered. In light of these considerations, secrecy would appear to represent the more appropriate, as well as the more effective, form of protection against the harmful impact of accusatory testimony in pre-prosecutorial investigations.

Given the importance of purpose as a determinant of agency need foropublic proceedings without safeguards under the analysis here proposed, what criteria may be used for ascertaining this factor? The lack of authority for the distinction between investigations which serve a general informing function and those which are bent on the discovery of prosecutorial information suggests that courts have been willing to assume that all non-adjudicatory proceedings serve a valid informing function or that they have regarded the distinction as irrelevant to the requirements of due process. The distinction is not limited in its applicability to the investigations of multi-purpose regulatory agencies, since congressional hearings may in fact serve as pre-prosecutorial investigations. ${ }^{.1}$ The prospects for its workable application, however, are greater in the administrative arena. The institutional stratification of the typical administrative agency is itself an initial guide; initiation of an investigation by a particular branch of the agency or the selection of particular personnel to conduct the proceeding will suggest its purpose. The circumstances of the FTC's Kroger

Since the public proceeding was to be adjudicatory in nature, however, the petitioner had a right to the trial-type hearing provided for by the Federal Trade Commission Act. Section 5(b), 38 Stat. 719 (1914), 15 U.S.C. \& 45(b) (1958). See also Myers v. Bethlehem Shipbldg. Corp., 303 U.S. 41, 47-48, $51-52$ (1938).

51. See, e.g., Barth, Governarent by Investigation 77-79 (1955). 
hearings illustrate some further indicia of purpose. The language in the Commission's announcement at the outset of the milk-pricing hearings, and in its subpoenas to Kroger and other involved companies, indicate that it was principally concerned with uncovering evidence of specific statutory violations. ${ }^{\text {ta }}$ The FTC Chairman even stated publicly that the purpose of the investigation was "to determine expeditiously whether pricing practices in the sale of milk should be made the subject of a formal adjudication" ${ }^{53}$ in this somewhat extraordinary instance, the very words indicated that the investigation was narrowly focused and pre-prosecutorial. ${ }^{54}$ In such circumstances a court should not hesitate to invalidate public proceedings. Where the external indicia are inconclusive, courts should permit a direct inquiry into the agency's purpose. They need not be deterred from requiring the testimony of agency officials on this issue by the considerations which militate against application of this technique to congressional investigations. ${ }^{55}$ Though it is unlikely that stuch testimony would often produce an unqualified admission of a pre-prosecutorial purpose, it seems equally improbable that the response of responsible agency officials, such as the commissioners, would often be untrue or distorted. Regardless of the indicia which are viewed as conclusive in particular instances, the

52. The subpoenas initially issued to Kroger and the other two interstate chains stated that the purpose of the hearings was to obtain information on possible violations of $\$ 2$ of the Robinson-Patman Act, 49 Stat. 1526 (1936), 15 U.S.C. § 13(a) (1958), amending Clayton Act, § 2, 38 Stat. 719 (1914), 15 U.S.C. \$ 45 (1958), prohibiting unfair methods of competition. FTC News Release, Feb. 28, 1962, TrADE REG. REp. If 10114.10 (1962). In resubpoenaing Kroger, the FTC referred to violations of "any law administered by the FTC." FTC News Release, April 27, 1962, Trade Reg. Rep. \1 10114.11 (1962).

53. Dixon, The Federal Trade Commission at 27.

54. ${ }^{\circ}$ In Archer v. Lemke, Trade Reg. Rep. (1962 Trade Cas.) If 70417 (N.D. Ill. July $20,1962)$, the District Judge who had issued the restraining order in the principal case again granted injunctive relief against a scheduled public milk-pricing hearing by the FTC. The hearings had been scheduled to begin in Denver on July 24 ; after the issue of the restraining order, the Commission scheduled nonpublic hearings and reissued the subpoenas to the companies previously served. See TRADE REG. REP. \| 10118.11-12 (1962).

At the least Archer appears to be a less straightforward case, though the court framed restraining orders in terms virtually identical to those of its previous order in Hall. The Denver hearings were scheduled pursuant to a broad investigative resolution setting forth the various grounds of the Commission's interest in milk-pricing practices and proclaiming its pursuit of a legislative purpose. This resolution, issued on July 3,1962, provides that, "in the public interest and in compliance with the Commission's Rules of Practice, all investigational hearings [shall] be conducted in public unless otherwise specificd in the formal processes authorized by the Commission." 27 Fed. Reg. 6682 (July 13, 1962).

The number of companies subpoenaed for the Denver hearings was also considerably larger than in Hall, see Trade Reg. Rep. If 10118.11-12 (1962), a circumstance which in combination with the above resolution would have lent substance to a claim by the FTC that it was engaged in a valid informing function. Morover, the result in Hall may have been based in part on the court's evaluation of the record from fifteen previous days of public hearings, while in Archer the court had no comparable basis for a judgment as to purpose. Lastly, the Commission's formal announcement of the Denver hearings contained no reference to suspected violations of law. FTC Release, July 6, 1962, TRADE REG. REP. If 10118.10. These considerations suggest that a more extensive inquiry into purpose should have been undertaken in Archer. See also text at notes 55-56 infra.

55. See Bickel, The Least Dangerous Branch 215-17 (1962). 
essential point is that courts recognize the issue of agency purpose as one of fact and as one which should not be confused with the separable and prior question of the agency's statutory authority for holding informative hearings. While an agency may be authorized to hold several types of investigative proceedings, ${ }^{56}$ it is only through close scrutiny of the circumstances in individual instances that relevant distinctions between these types may be discerned and appropriate procedural requirements imposed.

For those to whom the distinction between hearings intended to inform and hearings intended to ferret out facts for prosecution is not meaningful, either because they do not consider the needs of the informing function of sufficient importance to be determinative of due process requirements or because they believe the evidentiary problems involved in ascertaining the purpose of a particular proceeding would make the protection illusory, another approach to reconciling the relative needs of the agency and affected parties may be appealing. It should be recognized, however, that this approach does not follow from the premises developed in this Note. If the agency's statute clearly authorizes it either to recommend legislation or to fashion rules but does not specifically provide for public hearings, a court could require that potentially defamatory testimony be taken in private. ${ }^{.7}$ If public informing hearings are specifically authorized, the agency should have the choice of taking potentially defamatory testimony in private or granting procedural protections-e.g., cross-examination and rebuttal testimony to individuals who have been or are likely to be defamed and degraded by testimony not inadvertently elicited. An examination of the contrast between the Civil Rights Act and the Federal Trade Commission Act will illustrate the operation of this approach. There is abundant evidence that the leitmotiv of the former statute was the development of legislative information and recommendations in a highly complex and unexplored area. ${ }^{58}$ The statute expressly provided for public hearings, but required that potentially defamatory statements be taken in private. ${ }^{80}$ The FTC Act, on the other hand, while authorizing the Commission specifically to develop legislative recommendations, ${ }^{00}$ did not address itself to the problem of

56. Note the broad enabling clause of the FTC Act, which authorizes the Commission "to gather and compile information concerning, and to investigate from time to time the organization, business, conduct, practices, and management of any corporation engaged in commerce. ..." Section 6(a), 38 Stat 721 (1914), 15 U.S.C. $\$ 46(a)$ (1958). For discussion of the FTC's various uses of this power, see 1 facChesney \& Mfurphy, Intestigatory and Enforcement Powers of the Federal Trade Commission, 8 GEo. WASE. L. REv. 581 (1940); Note, 62 Coluns. L. Rev. 671, 679-80, 684-89 (1962).

57. Similar conditions have been attached to the enforcement of investigative subpoenas where there is a substantial possibility that trade secrets will be disclosed. See FCC $v$. Schreiber, 201 F. Supp. 421, 425 (S.D. Cal. 1962) ("it is ordered that the Examiner confine attendance at the hearing to the persons directly involved in the proceedings, their counsel, experts and witnesses and exclude the general public").

58. See Civil Rights Act of 1957, \& 104(a) (b), 71 Stat. 635 (1957), 42 U.S.C. § 1975 c(a) (b) (1958) ; Hannah v. Larche, 363 U.S. 420, 440-41 (1960).

59. 71 Stat. 634-35 (1957), 42 U.S.C. § $1975 \mathrm{a}(\mathrm{e})$, (g), (i) (1958).

60. 38 Stat. 721-22 (1914), 15 U.S.C. § 46(f) (1958). 
public hearings ${ }^{61}$ or safeguards. ${ }^{82}$ The FTC has failed to provide any selflimiting standards, asserting an unbounded discretion under the statute, and acknowledging no responsibility for protecting witnesses. ${ }^{63}$ An ambiguouslymotivated FTC public proceeding might, therefore, be strictly scrutinized by a court, which could direct the use of executive sessions whenever stubstantial injury to reputation appears imminent. The primary advantage of resolving the problem in this fashion would be to afford some protection to witnesses where the manifest purposes of an investigative proceeding are mixed or ambiguous, and thus a dominant pre-prosecutorial purpose cannot be ascertained. Its principal disadvantage would be the obstacles which either secrecy or cross-examination and similar trial-type procedures might pose to the effective exercise of the informing power. If the proceeding is in fact designed to inform, secrecy would impair the free flow of information, confrontation with one's accusers would seem to have very little meaning, and cross-examination of adverse witnesses would seem beside the point.

61. The terms of $\S 6(f)$ itself detract somewhat from the FTC's claim to possess statutory authorization for what Kroger called a play-by-play broadcast of the investigation. That section gives the Commission the power "to make public from time to timc such portions of the information obtained by it hereunder ... as it shall deem expedient in the public interest." (Emphasis supplied.) Kroger argued in addition that the duty of the Commission to subject evidence and testimony to a sifting and weighing process before releasing it to the public could be inferred from Congress' use of the term "information". Reply Brief for Plaintiff, p. 20, Hall v. Lemke, Trade Reg. Rep. (1962 Trade Cas.) $\int 70338$ (N.D. III. May 7, 1962).

62. See Hearts of Oak Assurance Co. v. Attorney-General (1932) A.C. 392, where the House of Lords held that the Industrial Assurance Commissioner had no power to conduct a public inquiry into a company subject to his statutory jurisdiction. In construing the Industrial Assurance Act, which was silent on the question, Lord MacMillan observed that:

[T] here is also no provision for the parties under suspicion being afforded any indication of the offenses of which they are suspected, or being permitted to be represented or defend themselves in any way, although, if the Attorney-General is riglit, the as yet unverified suspicions of the Commissioner or his inspector may be made public and communicated to the press. Anything more repugnant to elementary ideas of fairness and propriety it would be difficult to conceive.

$I d$. at 402 . This case suggests that an appropriate rationale for requiring private hearings where an agency lacks specific authorization for public hearings and the purpose is not clearly an informing one would be along the lines of Greene v. McElroy, 360 U.S. 474, 496-99, 507-08 (1959) ; cf. American Power \& Light Co. v. SEC, 329 U.S. 90, 108 (1946).

63. See Brief for Defendant, pp. 18-19, 32-33, Hall v. Lemke, Trade Reg. Rer. (1962 Trade Cas.) If 70338 (N.D. Ill. May 7, 1962). 